\title{
Chemical composition and antioxidant capacity of coffee pulp
}

\section{Composição química e capacidade antioxidante da polpa do café}

\author{
Graciela Munguía Ameca', María Esther Ortega Cerrilla', Pedro Zetina Córdoba ${ }^{2 *}$, \\ Antonio Díaz Cruz ${ }^{3}$, Marcos Soto Hernández', José Herrera Haro'
}

\author{
${ }^{1}$ Colegio de Postgraduados, Programa de Ganadería, Texcoco, México \\ 2Universidad Politécnica de Huatusco, Unidad Académica de Biotecnología y Agroindustrial, Huatusco, Veracruz, México \\ 3Universidad Nacional Autónoma de México/UNAM, Ciudad de México, México \\ *Corresponding author: prof-agroindustrial@uphuatusco.edu.mx \\ Received in January 10, 2018 and approved in May 15, 2018
}

\begin{abstract}
Coffee pulp is produced in large quantities, and its disposal can pollute the environment. However, the nutritional value and antioxidant content of coffee pulp make it a good option for animal feed. Therefore, the objective of this study was to determine the chemical composition, the phenolic compounds and the antioxidant capacity of coffee pulp using fresh (FCP), ensiled (ECP), and ensiled and sun-dried (EDCP) coffee pulp. The study design was completely randomized with three treatments $(n=4)$. Dry matter (DM), crude protein (CP), ash, acid detergent fiber (ADF), neutral detergent fiber (NDF), lignin, phenolic compounds and antioxidant capacity were determined. Data were analyzed by analysis of variance, and means were compared with the Tukey test. The percentage of CP, NDF and ADF was higher in ECP and EDCP than in FCP. There were no changes in lignin content. Ensiling and sun drying did not decrease $(P>0.05)$ caffeine or tannins. No differences were found in caffeic acid $\left(2.031 \pm 2.873,5.103 \pm 0.391,4.913 \pm 0.018 \mathrm{mg} \mathrm{g}^{-1} \mathrm{DM}\right.$ in FCP, ECP, EDCP, respectively). The concentration of chlorogenic acid (FCP 2.593 \pm 1.756 ; ECP 5.368 $\pm 0.422 ;$ EDCP $4.875 \pm 0.678$ mg g ${ }^{-1}$ ) increased with the ensiling process, but it was not affected by sun drying. Ethanol decreased in ECP and EDCP relative to FPC (FPC 15.88 $0.97 \%$; ECP $7.04 \pm 1.16 \%$; EDCP $0.00 \%$ ); however, antioxidant capacity was not affected. It was concluded that the ensiling process and sun drying affected the nutritional value of coffee pulp but not its antioxidant capacity.
\end{abstract}

Index terms: Phenolic acids; caffeine in coffee pulp; ethanol silage.

\section{RESUMO}

A polpa de café é produzida em grandes quantidades e sua eliminação contribue para a poluição do ambiente. Não entanto, seu alto valor nutricional e capacidade antioxidante a torna uma opção para a alimentação animal. O objetivo deste estudo foi determinar a composição química, o teor de compostos fenólicos e a capacidade antioxidante da polpa de café fresco (PCF), ensilada (PCE) ou ensilada e seca ao sol (PCED). O delineamento experimental foi inteiramente casualizado com três tratamentos ( $n=4)$. Matéria seca (MS), proteína bruta (PB), cinzas (CEN), fibra em detergente neutro (NDF), fibra em detergente ácido (ADF), lignina, compostos fenólicos e capacidade antioxidante foram avaliadas. Os dados foram analisados por análise de variância e as médias pelo teste de Tukey. A percentagem de PB, NDF e ADF foi maior no PCE, e PCED em relação ao PCF. Nenhuma alteração no teor de lignina foi encontrado. Silagem e desidratação ao sol não afetou o teor de cafeína ou tanino. Não houve diferença na proporção de ácido caféico $(2,031 \pm 2,873,5,103 \pm 0,391,4,913 \pm 0.018$

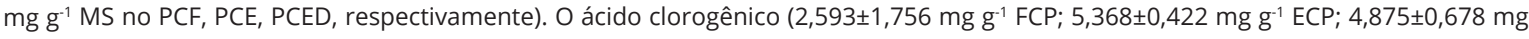
$\left.\mathrm{g}^{-1} \mathrm{EDCP}\right)$ aumentou com o processo de ensilagem, mas não foi afetado pela desidratação ao sol. $\mathrm{O}$ teor de etanol decreceu no $P C E$ e

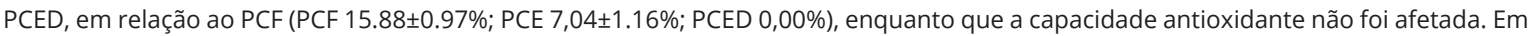
concluão o processo de ensilagem e a deshidratacão ao sol afetou o valor nutritivo, mas não a capacidade antioxidante da polpa de café.

Termos de indexação: Ácidos fenólicos; cafeína em polpa de café; ensilagem de etanol.

\section{INTRODUCTION}

After harvest, coffee berries need to be processed before their use and commercialization. This process can be done using two methods, i.e., the dry and wet methods (Berecha; Lemmessa; Wakjira, 2011). In the wet industrial process, coffee pulp is the main by-product and represents $55 \%$ of the whole berry (Murthy; Naidu, 2012). Ripe coffee fruits are harvested, and the skin and pulp are removed from the coffee beans (Duangjai et al., 2016). Most of the coffee pulp generated during wet processing is deposited directly into huge waste disposal sites or river streams without undergoing any treatment (Geremu; Bekele; Sualeh, 2016). The coffee pulp has been used to produce bioethanol (Menezes et al., 2014), biogas (Corro et al., 2013), compost (Bernas, 2011), substrate for mushrooms (Salmones; Mata; Waliszewki, 2005) and animal feed (Salinas-Rios et al., 2015). As a byproduct, 
coffee pulp contains associated bioactive compounds, such as polyphenols with good antioxidant properties, which endow additional health benefits (Geremu; Bekele; Sualeh, 2016), and anthocyanins that have potential applications as natural food colorants (Murthy; Naidu, 2012). The polyphenols can prevent or decrease the peroxidation of fatty acids, reduce oxidative stress in animals at critical physiological stages (Salinas et al., 2014), and increase the shelf life of animal meat when it is included in their diets (Salinas-Ríos et al., 2014). Ensiling coffee pulp is a viable process, and some chemical composition studies have showed that, compared with fresh coffee pulp, silage has higher crude protein content and lower values of nitrogenfree extracts and tannin; additionally, the antioxidant capacity of coffee pulp remains unchanged during the ensiling process (Salazar et al., 2009; Salinas et al., 2014).

The objective of this study was to assess the chemical characteristics, presence of antioxidant compounds and antioxidant capacity of coffee pulp, including fresh pulp, pulp ensiled with 5\% molasses, and ensiled and sundried pulp.

\section{MATERIAL AND METHODS}

\section{Location of the study area and establishment of the silo}

Coffee pulp was obtained from a de-pulping plant that uses the wet method to remove the berry from the coffee (Coffea arabica) bean. The de-pulping plant is in the municipality of Huatusco, Veracruz, Mexico $\left(19^{\circ} 09^{\prime} \mathrm{N}\right.$ and $96^{\circ} 58^{\prime} \mathrm{W}, 1344 \mathrm{~m}$ altitude). The coffee pulp was drained for $12 \mathrm{~h}$ to eliminate any water it absorbed during the depulping process (fresh coffee pulp, T1: FCP). Afterwards, the pulp was then placed in four plastic 1100-L capacity containers, and 5\% molasses was added for a 140-day fermentation process to obtain ensiled coffee pulp (T2: ECP). Immediately, part of the ensiled coffee pulp was sun dried for eight days to reduce water content (ensiled sundried coffee pulp, T3: EDCP).

At ensiling, samples were collected from each container in a similar manner. When the silos were opened, samples were taken from the upper, middle and lower parts and mixed to obtain a single sample for future analysis.

\section{Analyses performed on fresh, ensiled, and ensiled and sundried coffee pulp}

FCP, ECP, and EDCP were analyzed for dry matter $(\mathrm{DM})$, crude protein $(\mathrm{CP})$, ether extract (EE) and ash (AOAC, 1990). Additionally, coffee pulp samples were analyzed for neutral detergent fiber (NDF), acid detergent fiber (ADF) and lignin (Van Soest; Robertson; Lewis, 1991). Ethanol content was determined following the technique of Davies and Chace (1969). Five mL of HPLC grade $\mathrm{H}_{2} \mathrm{O}$ was added to $200 \mathrm{mg}$ of the sample from each of the treatments (i.e., FCP, ECP, and EDCP) to quantify the phenolic acids and caffeine. The mixture was shaken in a vortex and spent $30 \mathrm{~min}$ in a shaker (Heidolph), and then the sample was centrifuged at $4500 \mathrm{rpm}$ for $10 \mathrm{~min}$. Two milliliters of the supernatant was filtered through a nylon acrodisc filter ( $0.45 \mu \mathrm{m}$ diameter) and deposited into amber vials $(2 \mathrm{~mL})$. Phenolic acids were determined using a high precision liquid chromatograph (Agilent Technologies, Model 1100 with a photodiode array detector and a Nucleosil column Model Nautilus $<18$ 100-5, $125 \times 4$ $\mathrm{mm}$ ), with HPLC grade $\mathrm{H}_{2} \mathrm{O}$ in channel A; furthermore, the $\mathrm{pH}$ was 2.5 after being adjusted using trifluoroacetic acid and acetonitrile in channel $\mathrm{B}$. The gradient was as follows: $\min 10, \mathrm{~A}: 85 \%$, B: $15 \%$; $\min 20, \mathrm{~A}: 65 \%$, B: $35 \%$; and $\min 23, \mathrm{~A}: 65 \%$, B: $35 \%$. The flow rate was $1 \mathrm{~mL}$ per min at $30^{\circ} \mathrm{C}, 20 \mu \mathrm{L}$ of the sample was injected, and the reading was taken at $280 \mathrm{~nm}$. The phenolic acid standards were Sigma (e.g., gallic, chlorogenic, syringic, vanillic, 2,5-di-hydroxybenzoic, caffeic, p-hydroxybenzoic, 2,3-dihydroxybenzoic, ferulic and p-cumaric acids).

Caffeine was quantified by isocratic analyses using water and HPLC grade acetonitrile in a 75:25 proportion with a Nucleosil column (similar to that used for phenolic acid determination), into which $10 \mu \mathrm{L}$ of the sample was injected at a flow rate of $0.8 \mathrm{~mL}$ per min at $25^{\circ} \mathrm{C}$, and the reading occurred at $273 \mathrm{~nm}$. Caffeine (Merk) was used at concentrations between 2 and $12 \mu \mathrm{g}$ to generate a standard curve with 5 points.

Tannins were analyzed in three phases: 1) $10 \mathrm{~mL}$ of $70 \%$ acetone was added to a $25 \mathrm{mg}$ sample of coffee pulp, which was placed in an ultrasound bath (Brasonic model 220) for $10 \mathrm{~min}$, spent $5 \mathrm{~min}$ in repose and underwent 10 min of sonification. Samples were immediately centrifuged at $5000 \mathrm{rpm}$ for $10 \mathrm{~min}$. The supernatant was collected and put on ice. 2) $1 \mathrm{~mL}$ of distilled $\mathrm{H}_{2} \mathrm{O}$ was added to $100 \mathrm{mg}$ polyvinyl pyrrolidone (PVPP) and $1 \mathrm{~mL}$ of the extract with tannins. This mixture was shaken and stored at $4{ }^{\circ} \mathrm{C}$ for $15 \mathrm{~min}$, shaken for $1 \mathrm{~min}$ and centrifuged at $3000 \mathrm{rpm}$ for 5 min. The supernatant was collected and put on ice. 3) A standard curve was obtained using $0,2,4,6,8$ and $10 \mu \mathrm{g}$ solutions of tannic acid prepared from a mother solution (0.1 $\left.\mathrm{mg} \mathrm{mL}^{-1}\right)$, distilled $\mathrm{H}_{2} \mathrm{O}$ (i.e., 500, 480, 460, 440, 420, and $400 \mu \mathrm{L}$ ), folin reagent (i.e., $250 \mu \mathrm{L}$ ) and $20 \%$ sodium carbonate $(1.250 \mathrm{~mL})$. The mixture was measured using a spectrophotometer (Agilent Technologies Model 1100) at an absorbance wavelength of $725 \mathrm{~nm}$ (Makkar, 2003). 


\section{Antioxidant capacity}

Samples of extracts from FCP, ECP and EDCP were obtained. With these pulp samples, the antioxidant capacity was determined by the ferric reducing antioxidant power (FRAP) method (Benzie; Strain, 1999).

\section{Statistical analysis}

The experimental design was completely randomized with three treatments $(\mathrm{n}=4)$. The procedure PROC GLM (SAS, Cary, NC, USA, 2002) was used, and means were compared with the Tukey test $(\mathrm{P}<0.05)$. All variables were subjected to a normality test using the Univariate procedure.

\section{RESULTS AND DISCUSSION}

\section{Chemical composition}

Table 1 shows the chemical composition of the treatments. Dry matter content was affected $(\mathrm{P}<0.05)$ by the ensiling and drying processes, and the lowest value was observed in ECP. The DM value $(22.95 \pm 0.49 \%)$ in FCP was similar to the value of $23.20 \%$ reported by another study (Elias, 1978), as was the value found in ECP $(18.85 \pm 0.96 \%)$, which was close to the $15.40 \%$ obtained in a previous study (Bautista et al., 2005).

The concentration of crude protein $(\mathrm{CP})$ tended to increase $(\mathrm{P}<0.05)$ in FCP $(10.85 \pm 0.17 \%)$, ECP $(13.10 \pm 0.26 \%)$ and EDCP (13.24 $\pm 0.13 \%)$; however, ECP and EDCP were not significantly different $(\mathrm{P}>0.05)$. Similar results have been reported, with increments in CP from FCP $(9.12 \%)$ to ECP (13.14\%) and from $11.60 \%$ in FCP to $12.00 \%$ in ECP (Cardona et al., 2002). The ensiling process increased the percentage of $\mathrm{CP}$, probably due to the associated decrease in soluble carbohydrates. Protein content in the pulp was not affected by sun drying.

The EE of FCP was not affected by the ensiling and dehydration processes $(\mathrm{P}>0.05), \mathrm{FCP}(1.21 \pm 0.05 \%)$, ECP $(1.48 \pm 1.03 \%)$ and $\operatorname{EDCP}(1.72 \pm 0.99 \%)$. The results of ether extract in ensiled coffee pulp were similar to those found in previous studies (Moreau et al., 2003). In EDCP, the reported EE values were 2.8 and $1.34 \%$ (Figueroa; Mendoza, 2010), which were similar to the values observed in our study; however, in FCP, the value of EE was below 3.86\% (Noriega; Silva; García, 2009) but above 0.48 (Braham; Bressani, 1978).

The values of NDF and ADF increased $(\mathrm{P}<0.05)$ in EDCP, although there were no differences $(\mathrm{P}>0.05)$ in NDF between FCP and ECP. ADF, however, was affected $(\mathrm{P}<0.05)$ by the ensiling process. This increase might have been caused by the soluble carbohydrates that mixed with the effluents produced during the ensiling process; these soluble carbohydrates were then lost when the ensiled coffee pulp was sun dried. Therefore, the fiber content increased, and the percentages of NDF, ADF, and lignin were higher (Salinas et al., 2014).

Although the percentage of lignin was similar $(\mathrm{P}>0.05)$ in FCP $(31.51 \pm 0.24 \%)$, ECP $(30.97 \% \pm 0.94)$ and EDCP $(31.26 \pm 0.98 \%)$, the resulting values were higher than those published by other authors (Oliveira et al., 2007). The high content of lignin in the silage of this experiment may have been due to the presence of

Table 1: Chemical composition of coffee pulp.

\begin{tabular}{crrrrc}
\hline \multirow{2}{*}{ Parameter (\%) } & \multicolumn{5}{c}{ Coffee pulp } \\
\cline { 2 - 6 } & \multicolumn{1}{c}{ FCP } & \multicolumn{1}{c}{ ECP } & EDCP & SEM & P $<F$ \\
\hline Dry matter & $22.95^{\mathrm{b}} \pm 0.49$ & $18.85^{\mathrm{c}} \pm 0.96$ & $91.13^{\mathrm{a}} \pm 0.96$ & 0.240 & 0.0001 \\
As \% of dry matter & & & & & \\
Crude protein & $10.85^{\mathrm{b}} \pm 0.17$ & $13.10^{\mathrm{a}} \pm 0.26$ & $13.24^{\mathrm{a}} \pm 0.13$ & 0.070 & 0.0001 \\
Ether extract & $1.21 \pm 0.05$ & $1.48 \pm 1.03$ & $1.72 \pm 0.99$ & 0.357 & 0.6403 \\
Neutral detergent fiber & $49.34^{\mathrm{b}} \pm 2.64$ & $50.95^{\mathrm{b}} \pm 2.30$ & $55.19^{\mathrm{a}} \pm 2.37$ & 0.864 & 0.0003 \\
Acid detergent fiber & $41.91^{\mathrm{c}} \pm 1.62$ & $46.60^{\mathrm{b}} \pm 2.04$ & $52.14^{\mathrm{a}} \pm 1.97$ & 0.667 & 0.0001 \\
Lignin & $31.51 \pm 0.24$ & $30.97 \pm 0.94$ & $31.26 \pm 0.98$ & 0.282 & 0.4152 \\
Ash & $7.40^{\mathrm{c}} \pm 0.01$ & $8.76^{\mathrm{b}} \pm 0.32$ & $10.82^{\mathrm{a}} \pm 0.41$ & 0.107 & 0.0001 \\
pH & $4.25^{\mathrm{a}} \pm 0.09$ & $3.90^{\mathrm{b}} \pm 0.10$ & $\mathrm{ND}$ & 0.034 & 0.0001 \\
\hline
\end{tabular}

FCP: fresh coffee pulp, ECP: coffee pulp ensiled with 5\% molasses, EDCP: coffee pulp ensiled and sun dried. ND: not determined . $a, b, c$ Different letters in the same row indicate significant differences.

SEM: standard error of the mean. 
coffee plant residues in the silage, the age at harvest, the environmental conditions and the variety of coffee used.

Ash content had significantly different $(\mathrm{P}<0.05)$ values among FCP $(7.40 \pm 0.01 \%)$, ECP $(8.76 \pm 0.32 \%)$, and EDCP (10.82 $\pm 0.41 \%)$. The increase could be due to soil contamination where the coffee pulp was sun dried or due to the addition of molasses (Salinas-Rios et al., 2014). Nevertheless, these values coincided with those obtained by other authors (Moreau et al., 2003; Cardona et al., 2002), i.e., 7.73 and $7.90 \%$, respectively, in FCP and $9.55 \%$ and $10.80 \%$, respectively, in ECP; furthermore, these values were higher than the value obtained for sundried coffee pulp, 6.60\% (Figueroa; Mendoza, 2010).

\section{Caffeine, tannins and ethanol}

Table 2 shows the results for caffeine, tannins, and ethanol. An increasing trend in caffeine content was observed in FCP, ECP, and EDCP $(18.60 \pm 0.31,25.49 \pm 2.88$ and $30.30 \pm 8.23 \mathrm{mg} \mathrm{g}^{-1} \mathrm{DM}$, respectively); however, the values were not significantly different $(\mathrm{P}>0.05)$. The ensiling and drying processes did not modify the initial levels of caffeine. However, even though caffeine is a factor that may limit the use of coffee pulp as animal feed, no adverse effects have been observed in productive ruminant variables that were fed fresh or dehydrated coffee pulp that were provided in different proportions of the diet, e.g., (Salinas-Rios et al., 2015) reported $0.05 \%$ of caffeine in ensiled coffee pulp and studied diets that included $8 \%$ and $16 \%$ of coffee pulp.

Tannin content was similar $(\mathrm{P}>0.05)$ among the three treatments, although there was an increase from FCP to ECP and a decrease in $\operatorname{EDCP}(3.50 \pm 0.016,4.49 \pm 0.023$ and $1.18 \pm 0.984 \mathrm{mg} \mathrm{g}^{-1} \mathrm{DM}$, respectively). The lack of differences may have been because the fermentation process in the silo did not modify the tannins; thus, their concentrations were maintained (Noriega; Silva; García, 2009).

Differences $(\mathrm{P}<0.05)$ were observed in the quantity of ethanol in FCP and ECP $(15.88 \pm 0.97$ and $7.04 \pm 1.16$ g $100^{-1} \mathrm{DM}$, respectively), but no ethanol was detected in EDCP. The ethanol present in ECP was higher than that reported by authors who asserted that they obtained between 2 and $2.5 \mathrm{~g}$ ethanol after fermenting fresh coffee pulp for $48 \mathrm{~h}$ at $28^{\circ} \mathrm{C}$ (Murthy; Naidu, 2010). The ethanol measured in our study was within the acceptable range of 10 to $30 \mathrm{~g} \mathrm{~kg}^{-1} \mathrm{DM}$ for silage (Kung; Shaver, 2001). Yeasts, gram-negative and gram-positive bacteria, and filamentous fungi were present in high numbers during the different stages of the de-pulping process (Schwan; Wheals, 2003). During coffee fermentation, some pectinolytic microorganisms were associated with the degradation of the pulp and mucilage (which is rich in polysaccharides), producing alcohols and acids and other metabolic compounds (Reis et al., 2014), which might have contributed to the production of ethanol in FCP as

Table 2: Caffeine, tannin, antioxidant compounds and antioxidant capacity (FRAP) in the coffee pulp.

\begin{tabular}{|c|c|c|c|c|c|}
\hline & \multicolumn{3}{|c|}{ Coffee pulp } & \multirow[b]{2}{*}{ SEM } & \multirow[b]{2}{*}{$\mathrm{P}<\mathrm{F}$} \\
\hline & FCP & ECP & EDCP & & \\
\hline Caffeine (mg g $\left.{ }^{-1} \mathrm{DM}\right)$ & $18.60 \pm 0.31$ & $25.49 \pm 2.88$ & $30.30 \pm 8.23$ & 2.78 & 0.1014 \\
\hline Tannins (mg g-1 DM) & $3.500 \pm 0.016$ & $4.490 \pm 0.023$ & $1.189 \pm 0.984$ & 0.945 & 0.1173 \\
\hline Ethanol (g $\left.100 \mathrm{~g}^{-1} \mathrm{DM}\right)$ & $15.88^{\mathrm{a}} \pm 0.97$ & $7.04^{b} \pm 1.16$ & $0.00 c$ & 0.307 & 0.0001 \\
\hline \multicolumn{6}{|l|}{ Antioxidants (mg g-1 DM) } \\
\hline p-hydroxybenzoic acid & $0.071^{a} \pm 0.006$ & $0.018^{b} \pm 0.021$ & $0.018^{b} \pm 0.001$ & 0.010 & 0.0311 \\
\hline Chlorogenic acid & $2.593^{b} \pm 1.756$ & $5.368^{\mathrm{a}} \pm 0.422$ & $4.875^{a} \pm 0.678$ & 0.34 & 0.0052 \\
\hline Ferulic acid & $4.256 \pm 6.019$ & $8.503 \pm 0.012$ & $4.256 \pm 6.019$ & 2.45 & 0.3642 \\
\hline Caffeic acid & $2.031 \pm 2.873$ & $5.103 \pm 0.391$ & $4.913 \pm 0.018$ & 0.851 & 0.0950 \\
\hline Syringic acid & $0.062^{\mathrm{a}} \pm 0.00$ & $0.036^{b} \pm 0.006$ & $0.039^{b} \pm 0.000$ & 0.003 & 0.0037 \\
\hline Gallic acid & $0.058^{b} \pm 0.012$ & $0.145^{a} \pm 0.036$ & 0.00 & 0.018 & 0.0050 \\
\hline Vanillic acid & $0.007 \pm 0.004$ & $0.017 \pm 0.013$ & $0.011 \pm 0.002$ & 0.006 & 0.5326 \\
\hline p-cumaric acid & $0.002 \pm 0.001$ & $0.002 \pm 0.001$ & $0.0004 \pm 0.001$ & 0.001 & 0.2917 \\
\hline FRAP (nmol Trolox ${ }^{-1} \mathrm{~mL}$ ) & $2769.9 \pm 88.61$ & $2594.7 \pm 100.82$ & $2486.3 \pm 306.16$ & 136.47 & 0.4382 \\
\hline
\end{tabular}

FCP: fresh coffee pulp, ECP: coffee pulp ensiled with 5\% molasses, EDCP: coffee pulp ensiled and sun dried $\mathrm{a}, \mathrm{b}$ : different letters in the same row indicate significant differences. SEM: standard error of the mean 
a consequence of the time elapsed from the de-pulping process and the ensiling of coffee pulp (i.e., 18 hours).

\section{Phenolic acids}

Eight phenolic acids were identified (Table 2). Ferulic, caffeic and chlorogenic acids were found in greater proportions, and they increased during the ensiling process but decreased when silage was sun dried. Differences $(\mathrm{P}<0.05)$ were found only for chlorogenic acid; although, the amount of chlorogenic acid was similar in ECP and EDCP $(\mathrm{P}>0.05)$. Syringic, vanillic and $\mathrm{p}$-cumaric acids were found in lower concentrations. Only chlorogenic, p-hydroxybenzoic, syringic and gallic acids were different $(\mathrm{P}<0.05)$.

Chlorogenic acid was not the most abundant, as has been reported in previous studies (Murthy; Naidu, 2012). The quantity of chlorogenic acid varies with the degree of maturation (Aerts; Baumann, 1994), the species and the other factors associated with coffee quality, such as the altitude and the presence or absence of shade, as well as resistance to some diseases (Humphrey; Macrae, 1987). However, chlorogenic acid has been identified as a potent inhibitor of lipid peroxidation in vitro and has shown possible anticarcinogenic activity in vivo (Kasai et al., 2000); furthermore, chlorogenic acid was one of the three most abundant phenolic acids in FCP, ECP, and EDCP.

\section{Antioxidant capacity}

Antioxidant capacity was not affected $(\mathrm{P}>0.05)$ by ensiling or sun drying (FCP: $2769.9 \pm 88.61$; ECP: 2594.7 \pm 100.82 ; EDCP: $2486.3 \pm 306.16$ nmol Trolox $^{-1}$ $\mathrm{mL}$ ) (Table 2), which supports the findings reported in previous studies (Salinas et al., 2014) for fresh and ensiled coffee pulp. The antioxidant capacity of fermented coffee pulp extracts can be attributed to the presence of phenolic substances (Palomino et al., 2015). However, the mechanisms that affect antioxidant activity during fermentation are extremely varied, and studies have shown that the ensiling process may cause considerable reductions in polyphenol concentrations (Weinberg et al., 2008). Our study found no differences in certain phenolic acids, which may have derived from a microbial hydrolysis reaction that increased the quantity of phenolic compounds; moreover, fermentation induces the structural breakdown of plant cell walls, leading to the liberation or synthesis of various antioxidant compounds (Hur et al., 2014).

\section{CONCLUSIONS}

Ensiling increased the percentages of CP, ADF, NDF and ash without affecting the content of lignin and
EE. The highest concentrations of CP, ADF, NDF, ash and lignin were observed in the ensiled sun-dried coffee pulp. The p-hydroxybenzoic and syringic acids decreased with the ensiling process and with sun drying; however, chlorogenic acid increased. The gallic acid increased with fermentation, but it was imperceptible in the sun-dried pulp. The ferulic, caffeic, vanillic and p-cumaric acids were not affected. The antioxidant capacity did not vary among the fresh, ensiled or dried ensiled pulp.

\section{ACKNOWLEDGEMENTS}

The authors are grateful to the Consejo Nacional de Ciencia y Tecnología (CONACYT) and FIDEICOMISO No. 167304 of the Colegio de Postgraduados.

\section{REFERENCES}

AERTS, R. J.; BAUMANN, T. W. Distribution and utilization of chlorogenic acid in coffee seedlings. Journal of Experimental Botany, 45:497-503, 1994.

ASSOCIATION OF OFFICIAL ANALYTICAL CHEMIST - AOAC. Official methods of analysis of association of Official Analytical Chemists. 15th ed. AOAC, Washington, D.C. 1990.

BAUTISTA, E. O. et al. Pulpa ecológica de café ensilada en la alimentación de alevines del híbrido Cachamay (Colossoma Macropomum X Piaractus Brachypomus). Revista Científica FCV-LUZ, 15:33-40, 2005.

BENZIE, I. F. F.; STRAIN, J. J. Ferric reducing/antioxidant power assay: Direct measure of total antioxidant activity of biological fluids and modified version for simultaneous measurement of total antioxidant power and ascorbic acid concentration. Methods in Enzymology, 299:1527, 1999.

BERECHA, G.; LEMESSA, F.; WAKJIRA, M. Exploring the suitability of coffee pulp compost as growth media substitute in greenhouse production. International Journal of Agricultural Research, 6:255-267, 2011.

BERNAS, S. M. Effect of coffee pulp compost and terrace on erosion, run off and nutrients loss from coffee plantation in Lahat Regency, South Sumatra. Journal of Tropical Soils, 16:161-167, 2011.

BRAHAM, J.; BRESSANI, R. Coffee pulp. Composition, technology and utilization. Institute of nutrition of Central America and Panama. Microfiche edition available. IDRC. Ottawa. 1978. 95p. 
CARDONA, M. G. et al. Establecimiento de una base de datos para la elaboración de tablas de contenido nutricional de alimentos para animales. Revista Colombiana de Ciencias Pecuarias, 15:240-246, 2002.

CORRO, G. et al. Generation of biogas from coffee-pulp and cow-dung co-digestion: Infrared studies of postcombustion emissions. Energy Conversion and Management, 74:471$481,2013$.

DAVIES, P. L.; CHACE, W. G. Determination of alcohol in citrus juice by gas chromatography analysis of headspace. Horticultural Science, 4:117-119, 1969.

DUANGJAI, A. et al. Comparison of antioxidant, antimicrobial activities and chemical profiles of three coffee (Coffea arabiga L.) pulp aqueous extracts. Integrative Medicine Research, 5(4):324-331, 2016.

FIGUEROA, H. J. G.; MENDOZA, J. Cuantificación de minerales K, Ca, Mg y P en café y pergamino de café (Coffea arábiga L. var. Typica). Revista Venezolana de Ciencia y Tecnología de Alimentos, 1(2):221-230, 2010.

GEREMU, M.; BEKELE, T. Y.; SUALEH, A. Extraction and determination of total polyphenols and antioxidant capacity of red coffee (Coffea Arabica L.) pulp of wet processing plants. Chemical and Biological Technologies in Agriculture, 3:25-30, 2016.

HUMPHREY, C. J.; MACRAE, R. Determination of chlorogenic acid in instant coffee using derivative spectrophotometry and its application to the characterization of instant coffee/chicory mixtures. In: Colloques Cientifique International Sur le Café, 12, 1987. p.179-186.

HUR, S. J. et al. Effect of fermentation on the antioxidant activity in plant-based foods. Food Chemistry, 160:346-256, 2015.

KASAI, $\mathrm{H}$. et al. Action of chlorogenic acid in vegetables and fruits as an inhibitor of 8-hydroxydeoxyguanosine formation in vitro and in a rat carcinogenesis model. Food and Chemical Toxicology, 38(5):467-471, 2000.

KUNG, L.; SHAVER, R. Interpretation and use of silage fermentation analysis reports. Focus on Forage, 3:1-5, 2001. Available in: <http://www.uwex.edu/ces/crops/uwforage/ Fermentation.pdf>. Access in: March, 13, 2016.

MAKKAR, H. P. S. Quantification of tannins in tree and shrub foliage. A Laboratory Manual. Kluwer Academic Publishers. Dordrecht, 102p, 2003.

MENEZES, E. G. et al. Optimization of alkaline pretreatment of coffee pulp for production of bioethanol. Biotechnology Progress, 30:451-462, 2014.
MOREAU, Y. et al. Dietary utilisation of protein and energy from fresh and ensiled coffee pulp by the Nile tilapia, Oreochromis niloticus. Brazilian Archives of Biology and Technology, 46:223-231, 2003.

MURTHY, P. S.; NAIDU, M. M. Recovery of phenolic antioxidants and functional compounds from coffee industry by-products. Food and Bioprocess Technology, 5:897-903l, 2010.

MURTHY, P. S.; NAIDU, M. M. Sustainable management of coffee industry by-products and value addition - A review. Resources Conservation and Recycling, 66:45-48, 2012.

NORIEGA, S. A.; SILVA, A. R.; GARCÍA, D. S. M. Composición química de la pulpa de café a diferentes tiempos de ensilaje para su uso potencial en la alimentación animal. Zootecnia Tropical, 27:135-141, 2009.

OLIVEIRA, S. A. et al. Replacing corn with coffee hulls or soy hulls in dairy cows diets: Intake, nutrient digestibility, and milk production and composition. Revista Brasileira de Zootecnia, 36:1172-1182, 2007.

PALOMINO, G. L. R. et al. Enhanced extraction of phenolic compounds from coffee industry's residues through solid state fermentation by Penicillium purpurogenum. Food Science and Technology, 34(4):704-711, 2015.

REIS, E. S. et al. Improvement of coffee beverage quality by using selected yeasts strains during the fermentation in dry process. Food Research International, 61:183-195, 2014.

STATISTICAL ANALYSIS SYSTEM INSTITUTE. User's guide: Statistic, version 9. SAS Institute, Inc., Cary, NC, USA. 2002.

SALMONES, D.; MATA, G.; WALISZEWSKI, K. N. Comparative culturing of Pleurotus spp. on coffee pulp and wheat straw: Biomass production and substrate biodegradation. Bioresource Technology, 96:537-544, 2005.

SALAZAR, A. N. et al. Composición química de la pulpa de café a diferentes tiempos de ensilaje para su uso potencial en la alimentación animal. Zootecnia Tropical, 27(2):135141, 2009.

SALINAS, R. T. et al. Changes in composition, antioxidant content, and antioxidant capacity of coffee pulp during the ensiling process. Revista Brasileira de Zootecnia, 43:492-498, 2014.

SALINAS-RIOS, T. et al. Carcass characteristics, physiochemical changes and oxidative stress indicators of meat from sheep fed diets with coffee pulp. Arquivo Brasileiro de Medicina Veterinaria e Zootecnica, 66(6):1901-1908, 2014. 
SALINAS-RIOS, T. et al. Productive performance and oxidative status of sheep fed diets supplemented with coffee pulp. Small Ruminal Research, 123:17-21, 2015.

SCHWAN, R. F.; WHEALS, A. E. Mixed microbial fermentation of chocolate and coffee. In: BOEKHOUT, T. R. V. (Ed.), Yeasts in Food. Behr's Verlag, Hamburg, p.426-459, 2003.
VANSOEST, P.J.; ROBERTSON, J. B.; LEWIS, B. A. Methods for dietary fiber, neutral fiber and no starch polysaccharides in relation to nutrition. Journal of Dairy Science, 74:3583-3597, 1991.

WEINBERG, Z. G. et al. Ensiling olive cake with and without molasses for ruminant feeding. Bioresource Technology, 99:1526-1529, 2008. 